\title{
Synthesis and Characterization of High-Performance Solar Cell
}

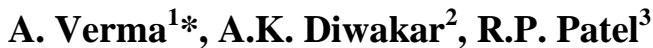 \\ ${ }^{1,2,3}$ Department of Physics, Kalinga University, Atal Nagar, Raipur (C.G.), India \\ *Corresponding Author: alokeverma1785@gmail.com
}

Available online at: www.isroset.org

Received: 07/Apr/2019, Accepted: 18/Apr/2019, Online: 30/Apr/2019

\begin{abstract}
High-performance solar-cell is designed for lead-free perovskite materials, synthesis of using for the organometallic halides. The perovskite materials having a high-efficiency charge carrier and identified low-cost materials based commercial photo-voltaic cell. It is an unusually breakthrough of the drawback of high-efficiency photo-voltaic solarcell because in this solar-cell replaced harmful lead using various perovskite materials like $\left(\mathrm{Sn}^{2+}, \mathrm{Ge}^{2+}, \mathrm{Mg}^{2+}, \mathrm{Ca}^{2+}, \mathrm{Sr}^{2+}\right.$, $\mathrm{Ba}^{2+}, \mathrm{Cu}^{2+}, \mathrm{Fe}^{2+}, \mathrm{Pd}^{2+}$, and $\left.\mathrm{Eu}^{2+}\right)$. We predict the structure and optical properties of perovskite solar-cell based on $\mathrm{Ge}$ and Sn solid solutions, $\mathrm{CH}_{3} \mathrm{NH}_{3} \mathrm{Sn}_{(1-\mathrm{x})} \mathrm{Ge}_{\mathrm{x}} \mathrm{I}_{3}(0 \leq \mathrm{x} \leq 1)$. This material is having the band gaps from 1.3 to $2.0 \mathrm{eV}$, and it is suitable for an optoelectronic application's range, from single junction devices and top cells for placement to light-emitting layer. The power efficiency of lead-free perovskite solar-cell (LFPSCs) is more than 27\%. Which has $\mathrm{ABO}_{3}$ type orthorhombic crystal structure and successfully examine its structure using X-ray diffraction (XRD) technology. In this research, we synthesis successfully lead-free perovskite solar-cell (LFPSCs).
\end{abstract}

Keywords - Perovskite material; Solar-cell; X-ray diffraction (XRD); Halides; Inorganic cation and anion; Methyl-ammonium.

\section{INTRODUCTION}

Last few years, in this field lots of work and developing many new types of solar cell material. Lead is a very harmful element for our environment. So we work on this field and remove to lead in solar cell and developing new type solar cell synthesis from $\mathrm{Sn}$ and Ge. It's a fourth generation solar cell full fill our requirement of energy and more efficient from the traditional solar cell. Perovskites material having lots of physical property one of the most important properties of these materials easily shows the PV properties. In this research we use orgenomatlic perovskite solar cell material $\mathrm{CH}_{3} \mathrm{NH}_{3} \mathrm{Si}_{(1-\mathrm{x})} \mathrm{Ge}_{\mathrm{x}} \mathrm{I}_{3}(\mathrm{x}=0.1,0.2,0.3,0.4,0.5)$ [1].This solar cell performance high efficient solar cell and having a traditional perovskite structure. Remarkable work on thin film fabrication such as thermal co-evaporation in high vacuum, sequential deposition, vapor assisted solution process (VASP), chemical vapor deposition, solvent engineering, intermolecular exchange, has led to this extreme development [2]. The lead-free perovskite materials for solar cell application reported so far, tin-based perovskites which have the chemical formula of $\mathrm{ASnX}_{3}$ where $\mathrm{A}$ can be $\mathrm{Ge}$, methylammonium (MA) and $\mathrm{X}$ can be $\mathrm{I}, \mathrm{Br}, \mathrm{Cl}$ or $\mathrm{F}$, are the most promising substitutions since $\mathrm{Sn}$ and $\mathrm{Pb}$ both belong to group 14 of the periodic table and thus are predictable to possess comparable physical and chemical properties. As a result, the nature of the chemical bonding becomes more covalent in the case of $\mathrm{ASnI}_{3}$ systems because of the relatively larger degree of orbital overlap in the shorter Sn-I bond compared to the $\mathrm{Pb}-\mathrm{I}$ bond. The consequences of this subtle difference in chemical bonding have a strong impact on the semiconducting properties of the materials.

\section{EXPERIMENTAL METHOD}

First, of make $4 \mathrm{~mm} \mathrm{TiO}_{2}$ thin layer using by sole-gel process and vapor deposition of a compact layer of $\mathrm{TiO}_{2}$ using annealing at $450^{\circ} \mathrm{C}$ for 30 minutes, and after then cooled at room temperature gradually. After the $\mathrm{TiO}_{2}$ layer prepared $\mathrm{CH}_{3} \mathrm{NH}_{3} \mathrm{Sn}_{(1-\mathrm{x})} \mathrm{Ge}_{\mathrm{x}} \mathrm{I}_{3}$ active layer. The synthesis of $\mathrm{CH}_{3} \mathrm{NH}_{3} \mathrm{Sn}_{(1-\mathrm{x})} \mathrm{Ge}_{\mathrm{x}} \mathrm{I}_{3}$ using equimolar quantities of $\mathrm{CH}_{3} \mathrm{NH}_{3} \mathrm{I}$, $\mathrm{SnI}_{2}$ and $\mathrm{GeI}_{2}$ concentration of $45 \mathrm{wt} \%$ was dissolved in a mixed solvent of DMF and DMSO-GBL with a ratio of 3.5:7. The schematic of the active layer deposition is shown in Fig. 2 [3]. The precursor solutions were spin coated onto $\mathrm{TiO} 2$ coated substrates to form a dark-brown tin perovskite layer [4]. Because of the $\mathrm{CH}_{3} \mathrm{NH}_{3} \mathrm{Sn}_{(1-\mathrm{x})} \mathrm{Ge}_{\mathrm{x}} \mathrm{I}_{3}$ gradually decomposed in the air, all the preparation of $\mathrm{CH}_{3} \mathrm{NH}_{3} \mathrm{Sn}_{(1-}$ ${ }_{x)} \mathrm{Ge}_{\mathrm{x}} \mathrm{I}_{3}$ films were performed in the nitrogen glove box to avoid hydrolysis and oxidation of tin perovskite layer in contact with rotating air [4]. Now successfully prepared leadfree perovskites solar cell (LFPSCs) using the organometallic compound. 


\section{CHARACTERIZATION}

The characterization of the solar cell basically shows its efficiency on different parameters. The morphologies of the $\mathrm{CH}_{3} \mathrm{NH}_{3} \mathrm{Sn}_{(1-\mathrm{x})} \mathrm{Ge}_{\mathrm{x}} \mathrm{I}_{3}$ layer and the fabricated perovskite solar cells were examined using a high-resolution scanning electron microscope and a focused ion beam assisted SEM [5]. The absorbance of the $\mathrm{CH}_{3} \mathrm{NH}_{3} \mathrm{Sn}_{(1-\mathrm{x})} \mathrm{Ge}_{\mathrm{x}} \mathrm{I}_{3}$ perovskite active layer was analyzed using a UV/Vis spectrometer in the wavelength range from 500 to $900 \mathrm{~nm}$. Photocurrent densityvoltage curves were recorded using a solar simulator equipped with a $450 \mathrm{~W}$ xenon [6]. An aperture mask was used while measuring the devices in reverse scan mode at $200 \mathrm{~ms}$ scan rate. The EQE was measured using a specially designed EQE system, wherein a $75 \mathrm{~W}$ xenon lamp was used as a light source to generate a monochromatic beam [7].

\section{RESULTS AND DISCUSSION}

Successfully examine of the XRD pattern of $\mathrm{CH}_{3} \mathrm{NH}_{3} \mathrm{Sn}_{(1-}$ ${ }_{x)} \mathrm{Ge}_{\mathrm{x}} \mathrm{I}_{3}$. The straight XRD measurement for all examined $\mathrm{CH}_{3} \mathrm{NH}_{3} \mathrm{Sn}_{(1-\mathrm{x})} \mathrm{Ge}_{\mathrm{x}} \mathrm{I}_{3}$ shows that their (110) peak strengths have no important diff erence and the order of $40 \%>20 \%>$ $10 \%>0 \%$, which is not steady with the PCE result. We also correlate the nanostructural of the films to the crystal orientation. For the perovskite films with internal pore network, the crystallites oriented to the out-of-plane direction dominate [8]. No crystallites with the in-plane coordination were speciously examine. The condensed perovskite films through surface fractal structural have the crystallites with outside of plane as well as inside plane orientations. Successfully examine of current-density $\left(\mathrm{mAcm}^{-2}\right) \mathrm{Vs}$ applied bias voltage (V) curves of the best execution solution-processed (blue lines, triangles) and vapourdeposited (orange lines, circles) lead-free perovskite solar cell LFPSCs [9].

\section{CONCLUSION}

For the experimental material synthesis using sol-gel and vapour deposition method, and successfully design LFPSCs. LFPSCs material characteristics like XRD, UV/Vis and Current-density $\left(\mathrm{mAcm}^{-2}\right) \mathrm{Vs}$ applied bias voltage $(\mathrm{V})$ curves successfully examine. Finally, we are success to improve efficiency of solar-cell and successfully examine and design of LFPSCs.

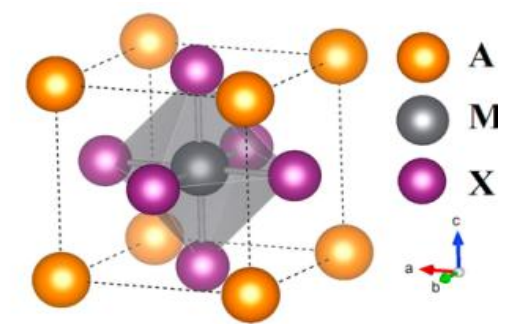

Figure 1 Perovskites structure of $\mathrm{AMX}_{3}$ where $\mathrm{A}-\mathrm{Ge}$ and $\mathrm{CH}_{3} \mathrm{NH}_{3}$, M- Sn, X- I
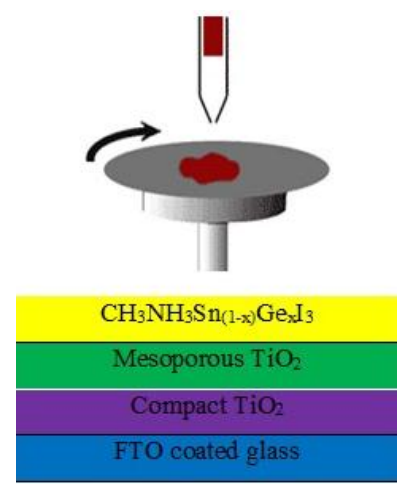

Figure 2 The schematics of the active layer of $\mathrm{CH}_{3} \mathrm{NH}_{3} \mathrm{Sn}_{(1-\mathrm{x})} \mathrm{Ge}_{\mathrm{x}} \mathrm{I}_{3}$ layer deposition. (a)

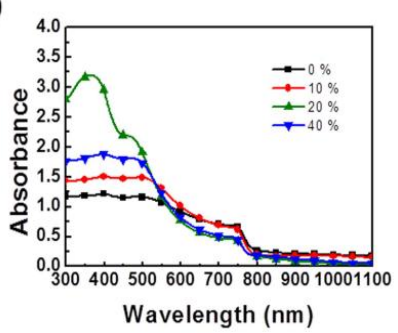

(b)

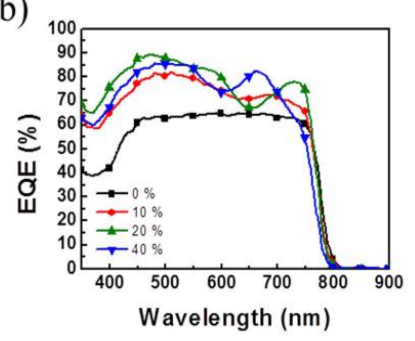

Figure 3 UV - absorption spectra of lead-free perovskite solar cell (LFPSCs) (a)

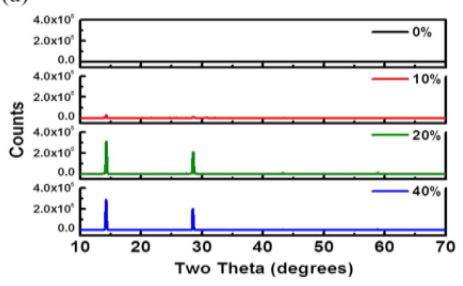

(b)

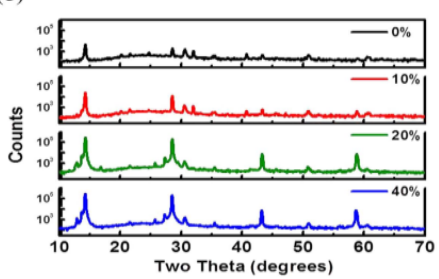

Figure 4 XRD patterns (a) in linear and (b) in logarithmic scale of the $\mathrm{CH}_{3} \mathrm{NH}_{3} \mathrm{Sn}_{(1-\mathrm{x})} \mathrm{Ge}_{\mathrm{x}} \mathrm{I}_{3}$ prepared with $0,10,20$ and $40 \%$ of iodide, respectively

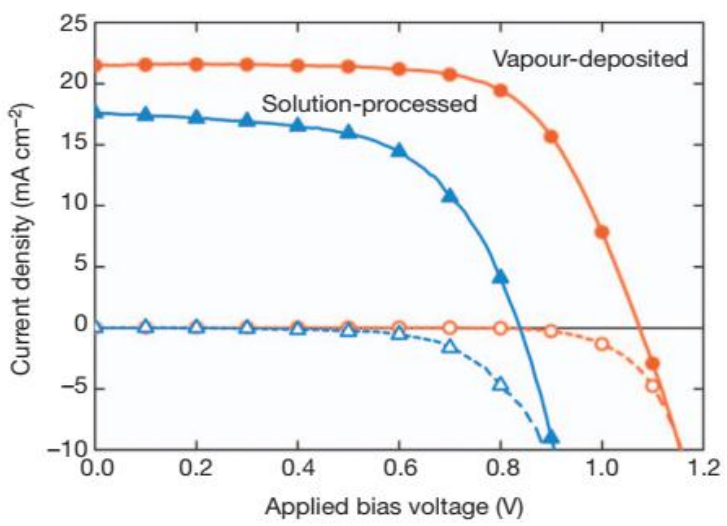

Figure 5 Current-density $\left(\mathrm{mAcm}^{-2}\right)$ Vs applied bias voltage (V) curves of the best execution solution-processed (blue lines, triangles) and vapour-deposited (orange lines, circles) lead-free perovskite solar cell LFPSCs 


\section{REFERENCES}

[1]. S. D. Wolf, J. Holovsky, S. Moon, P. Löper, B. Niesen, M. Ledinský, F.J. Haug, J. Yum, C. Ballif, "Organometallic Halide Perovskites: Sharp Optical Absorption Edge and Its Relation to Photovoltaic Performance", Journal of Physical Chemistry Letters 5(6):1035-1039, March 2014. DOI: 10.1021/jz500279b.

[2]. Chong Liu, Jiandong Fan, Xing Zhang, Yanjiao Shen, Lin Yang, Yaohua Mai, "Hysteretic Behavior upon Light Soaking in Perovskite Solar Cells Prepared via Modified Vapor-Assisted Solution Process", ACS Applied Materials \& Interfaces 7(17), April 2015. DOI: 10.1021/acsami.5b00375.

[3]. Hidetsugu Tamura, Masahiro Minagawa, Akira Baba, Kazunari Shinbo, Keizo Kato, Futao Kaneko, "Improvement of on/off ratio in organic field-effect transistor with carrier generation layer using oblique deposition", Japanese Journal of Applied Physics, Volume 55, Number 2S, January 2016.

[4]. Anastasiia Iefanova, Nirmal Adhikari, Ashish Dubey, Devendra Khatiwada, and Qiquan Qiaoa, "Lead free $\mathrm{CH}_{3} \mathrm{NH}_{3} \mathrm{SnI}_{3}$ perovskite thin-film with p-type semiconducting nature and metallike conductivity", AIP Advances, Volume 6, Issue 8, August 2016. DOI: $10.1063 / 1.4961463$.

[5]. Feng Xu, Ge Li, Taiyang Zhang, Yixin Zhao, “ Mixed Cation Hybrid Lead Halide Perovskites with Enhanced Performance and Stability", J. Mater. Chem. A. 5, January 2017. 10.1039/C7TA00042A.

[6]. Inyoung Jeong, Jea Woong Jo, Seunghwan Bae, Hae Jung Son, Min Jae Ko, "A fluorinated polythiophene hole-transport material for efficient and stable perovskite solar cells", Dyes and Pigments, Volume 164, May 2019, Pages 1-6. DOI: 10.1016/j.dyepig.2019.01.002.

[7]. Chong Liu, Jiandong Fan, Xing Zhang, Yanjiao Shen, Lin Yang, Yaohua Mai, " Hysteretic Behavior upon Light Soaking in Perovskite Solar Cells Prepared via Modified Vapor-Assisted Solution Process", ACS Applied Materials \& Interfaces 7(17), April 2015. DOI: 10.1021/acsami.5b00375.

[8]. Yu-Ching Huang, Cheng-Si Tsao, Yi-Ju Cho, Kuan-Chen Chen, Kai-Ming Chiang, Sheng-Yi Hsiao, Chang-Wen Chen, Chun-Jen $\mathrm{Su}$, U-Ser Jeng, Hao-Wu Lin, "Insight into Evolution, Processing and Performance of Multi-length-scale Structures in Planar Heterojunction Perovskite Solar Cells", Scientific Reports volume 5, Article number: 13657 (2015). DOI: 10.1038/srep13657.

[9]. Weibo Yan, Zilong Wang, Yuancai Gong, Shigan Guo, Jingjing Jiang, Jianhua Chen, Chengcheng Tang, Ruidong Xia, Wei Huang, Hao Xin, “ Naphthalene-diimide selenophene copolymers as efficient solution-processable electron-transporting material for perovskite solar cells", Organic Electronics Volume 67, April 2019, Pages 208-214. DOI: 10.1016/j.orgel.2019.01.040.

\section{AUTHORS PROFILE}

Mr. A Verma, M. Sc., M. Phil., and Ph. D. (Research Scholar) Physics from Kalinga University, Raipur. He has published more than 07 research papers in reputed international journals and conferences and it's also available online. His main research work focuses on solar cell.

Dr. A K Diwakar, Ph.D. Physics from Pt. Ravishnkar Shukla University, Raipur. He is currently working as Associate Professor in Department of Physics from Kalinga University, Raipur since 2018. He has published more than 15 research papers in reputed international journals including Thomson Reuters (SCI \& Web of Science) and conferences and it's also

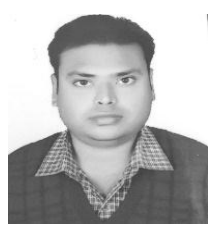
available online. His research area on Astrophysics and Solar Cell. He has 11 years of teaching experience and research experience.

Dr. R P Patel, Ph.D. Physics from Rani Durgavati University, Jabalpur. He is currently working as Professor and HOD in Department of Physics from Kalinga University, Raipur since 2018. He has published more than 26 research papers in reputed international journals including Thomson Reuters (SCI \& Web of Science) and conferences and it's also available online. His research area on Luminescence and Solar Cell. He has 20 years of teaching experience and research experience. Hs is also member of various journals of editorial board and reviewer. 